\title{
Utility of CD3 and CD30 in Immunophenotyping of Lymphomas Among Sudanese Patients
}

\author{
Hussain Gadelkarim Ahmed ${ }_{-}^{1 *}$, Tumadir Mohmmed Adam¹, Nagla.K.Basama² and Ahmed Abdulla Agabeldor ${ }^{3}$ \\ 1Department of Histopathology and Cytology, Faculty of Medical laboratory Sciences, Khartoum, Sudan \\ University of Gazira, Center of Bioscience and Biotechnology, Madani, Sudan \\ 3University of Kordofan, Faculty of medicine, Obied, Sudan
}

\section{Abstract}

Background and Aims: Phenotypic analysis of lymphomas is now considered compulsory for precise classification which is the starting point for best possible patient management. The aims of this study were to investigate the frequencies of T cell (using CD3) and Hodgkin's cell (using CD30) lymphomas in Sudan.

Methods: In this retrospective study, paraffin embedded tissue blocks from 62 patients with lymphomas and three patients with benign lymph proliferative disorders were studied. Although, all of the 65 specimens were immunostained for CD3, only 30 specimens were immunostained for CD30 expression.

Results: Out of the 62 cases of lymphomas, 13(21\%) were cases of Hodgkin's lymphoma and the remaining $49(79 \%)$ were Non-Hodgkin's lymphomas. Of the 62 cases immunostained for CD3 expression, 15(24\%) were identified as CD3-positive. Of the 30 cases immunostained for CD30 expression, 12(40\%) were demonstrated as CD30-positive, all of them from the cases of Hodgkin's lymphomas.

Conclusion: There is high frequency of T-cell lymphomas among Sudanese lymphoma's patients. CD30 marker has a reasonable specificity and sensitivity measures as a marker for identifying Hodgkin's lymphomas. Studies for immunophenotyping of lymphoma with extra markers are highly recommended.

\section{Introduction}

Cell marker analysis helps to determine whether the lymphoid cell population is composed of many different cells or if there is only one cell type present. Cell marker analysis can help determine whether B cells or T cells are present. CD3 is a human cell surface glycoprotein complex consisting of at least five different polypeptide chains [1]. These chains are closely associated with each other and also with $\mathrm{T}$ cell antigen receptor, and are involved in signal transduction following binding of antigen receptor. The CD3 antigen is expressed during thymopoiesis and on mature T cells in the periphery. It is also present in the majority of T cell Chronic Lymphocytic Leukemia (CLL) and T-lymphomas and in approximately $70 \%$ of $\mathrm{T}$ cell acute lymphoblastic leukemia (ALL). Cytoplasmic CD3 was demonstrated in $95 \%$ of thymocytes and in all T-ALL including those in which surface membrane CD3 was absent [2, 3]. In this study we used CD3 as a marker to distinguish between $\mathrm{T}$ - cell lymphomas and B cell lymphomas.

CD30 is a surface marker for neoplastic cells of Hodgkin's lymphoma and shows sequence homology to members of the tumor necrosis factor (TNF) receptor super family. This receptor is expressed by activated, but not by resting, T and B cells [4]. Immunohistochemical evaluation of CD30 expression is commonly performed in the assessment of hematopoietic disorders and germ cell tumors. Immunoreactivity was observed in all cases of classical Hodgkin lymphoma, anaplastic large cell lymphoma [5]. The current study used CD30 as a marker with the presence of Reed-Sternberg cells to group the classical Hodgkin's lymphomas.

However, disturbed expression of the TCR/CD3 complex and associated signaling molecules in CD30+ T-cell lymphoproliferations was reported [6]. Severely altered expression of the T-cell receptor/ CD3 complex, T-cell receptor-associated transcription factors and signal transduction molecules is a common characteristic of systemic and cutaneous $\mathrm{CD} 30+$ lymphoproliferations, although the clinical behavior of these entities is very different [7].
Non Hodgkin lymphomas are the most common lymphomas in the Sudan, as well as, relatively high frequency of T-cell lymphomas. Recent studies from developed countries have shown differences in survival for the different immunophenotypes. Such studies are lacking in the Sudan where diagnosis is largely dependent on morphology alone. Although, there are many markers available to distinguish T-cell and B cell lymphoma types as well as Hodgkin's lymphoma types, but we tested these two markers as they are most frequently used markers in this context in Sudanese Immunohistochemical Laboratories. Therefore, in this study we are trying to determine the prevalence of different types of lymphoma in Sudan population, as well as possible sub classification of lymphomas in to T cell and B cell types or Hodgkin's and Hodgkin's types in the Sudan.

\section{Methodology}

In this retrospective study, paraffin embedded tissue blocks from 62 patients with lymphomas and three patients with benign lymph proliferative disorders were retrieved from two histotechnology laboratories, as indicated in Table 1 . These were all the available continuous cases seen at our Histotechnology laboratories (during a period of 10 years). Clinical and pathologic information was obtained

*Corresponding author: Hussain Gadelkarim Ahmed, University of Khartoum, 102 Faculty of medical laboratory sciences, Khartoum, Sudan, E-mail: Hussain@uofk. edu, Hussaingad1972@yahoo.com

Received October 13, 2010; Accepted December 02, 2010; Published May 01 2011

Citation: Ahmed HG, Adam TM, Basama NK, Agabeldor AA (2011) Utility of CD3 and CD30 in Immunophenotyping of Lymphomas Among Sudanese Patients. Cancer Sci Ther 3: 116-119. doi:10.4172/1948-5956.1000071

Copyright: (C) 2011 Ahmed HG, et al. This is an open-access article distributed under the terms of the Creative Commons Attribution License, which permits unrestricted use, distribution, and reproduction in any medium, provided the original author and source are credited. 
by review of patients' medical records and surgical pathology reports and by review of H\&E-stained sections of the lymphomas. One pathologist retrospectively reviewed the H\&E-stained sections and two CD immunostains. All specimens which were obtained from cases of lymphomas and benign lymph proliferative disorders were immunostained for CD3 expression, hence, only 30 specimens out of the 62 cases of lymphomas were immunostained for CD30 expression.

Lymphoid tissue biopsies were fixed in neutral buffered formalin and embedded in paraffin. Sections of formalin-fixed, paraffinembedded tissue $(5 \mu \mathrm{m})$ were tested for the presence of CD3 and CD30 (Clone F7.2.38 and Ber-H2; DAKO, Denmark) using an avidin biotincomplex technique and water bath heat-induced antigen retrieval. An avidin-biotinylated enzyme complex kit (DAKO LSAB2 Denmark,) was used. Hematoxylin was used as counterstain. Appropriate positive controls were sections of Tonsil, previously used to determine the best dilution of antibody and to optimize the IHC technique. This positive control is run with all sections on which $\mathrm{CD} 3$ or $\mathrm{CD} 30$ immunohistochemistry is requested, so that its use is standardized and its specificity is known. Positive control slides are reviewed with each run to note any decreased sensitivity in any particular run. Negative controls had primary antibody replaced by buffer.

Immunohistochemistry staining was done adopting procedure described by Ahmed et al. [8] Sections were deparaffinized and rehydrated, then steamed in citrate buffer $(\mathrm{pH} \mathrm{6)}$ for 20 minutes and cooled for 20 minutes before immunostaining. All tissues were exposed to $3 \%$ hydrogen peroxide for 5 minutes, primary antibody (CD3 or CD30, DAKO, Denmark) for 60 minutes, biotinylated secondary linking antibody for 25 minutes, streptavidin enzyme complex for 25 minutes, diaminobenzidine as chromogen for 5 minutes, and hematoxylin as counterstain for 2 minute. These incubations were performed at room temperature; between incubations, sections were washed with Tris-Buffered Saline buffer (DAKO). Ethical consent: Permission to carry out the study was obtained from the Kordofan University Faculty of Medicine Research Committee.

\section{Results}

Of the 62 cases of lymphomas, 13(21\%) were patients with Hodgkin's lymphomas and the remaining 49 (79\%) were NonHodgkin's lymphomas of which 5(10\%) were cases of Burkett's lymphomas. The majority of patients were male (77\%). The mean age at diagnosis was 35 years (range, 2 to 80 years).

\begin{tabular}{|l|l|l|}
\hline Lymphatic disorder & Frequency & Percent \\
\hline Hodgkin's lymphoma & 13 & 20 \\
\hline Non-Hodgkin's lymphoma & 44 & 67 \\
\hline Burkitt's lymphoma & 5 & 8 \\
\hline Benign lymphproliferative & 3 & 5 \\
\hline Total & 65 & 100 \\
\hline
\end{tabular}

Table 1: Destribution of the study population by benign proliferative disorders.

\begin{tabular}{|l|l|l|l|l|l|l|}
\hline \multirow{2}{*}{$\begin{array}{l}\text { Lymphoma } \\
\text { type }\end{array}$} & CD3(Clone F7.2.38) & \multirow{4}{l|l}{ Total } & \multicolumn{2}{l|}{ CD30(Clone Ber-H2) } & Total \\
\cline { 2 - 6 } & Positive & Negative & & Positive & Negative & \\
\hline Hodgkin's & 1 & 12 & $13(p=4.8)$ & 11 & 2 & $13(p=0.01)$ \\
\hline $\begin{array}{l}\text { Non- } \\
\text { Hodgkin's }\end{array}$ & 14 & 35 & $49(p=0.07)$ & 1 & 16 & $17(p=88)$ \\
\hline Benign & 0 & 3 & 3 & - & - & 0 \\
\hline Total & $15(24 \%)$ & 50 & 65 & $12(40 \%)$ & 18 & 30 \\
\hline
\end{tabular}

Table 2: Immunoexpression of CD3 and CD30 in Hodgkin's, Non-Hodgkin's lymphoma and benign lymph proliferative disorders.
Of the 62 tissue sections immunostained for CD3 expression, 15(24\%) were identified as CD3-positive. Of the 30 cases immunostained for CD30 expression, 12(40\%) were demonstrated as CD30-positive. All of the 13(21\%) cases of Hodgkin's lymphomas were immunostained for CD30 expression. Out of the 13 cases of Hodgkin's lymphomas, CD30 positive expression was identified in $11(84 \%)$ cases. Out of the remaining 17 cases of Non-Hodgkin's that were immunostained for CD30, only one (6\%) was found as CD30 positive specimens of NonHodgkin's lymphomas. The three cases of benign lymph proliferative disorders were only immunostained for CD3 and all were found as, CD3-negative. Of the 13 specimens of Hodgkin's lymphomas, only one (7.7\%) specimen was found CD3 positive, hence, out of 49 specimens of Non-Hodgkin's lymphomas, 14 (28.6\%) specimens were found CD3 positive, as shown in Table 2 . These measures revealed sensitivity and specificity for CD30 constituting $84 \%$ and $94 \% \%$ respectively, for identifying of Hodgkin's lymphoma.

\section{Discussion}

Histopathological examination remains fundamental for diagnosis and classification of malignant lymphomas, but poses problems when characteristic features of specific lymphoma are not present. This raise up the value of immunohistochemistry. Experience with immunohistochemistry in developing countries is limited due to cost. Therefore, in this study, we have only used a monoclonal antibody to CD3 effective in paraffin sections to identify $\mathrm{T}$ cell lymphomas, and antibody to CD30 to identify Hodgkin's lymphoma. Accordingly, CD3 + was representing $24 \%$ which was very high in relation to what was reported in the literature worldwide. In a study from the Sudan Most cases of Burkett's lymphoma occurred in Southern Sudan. It is concluded that geographic and racial factors play important roles in determining the frequency and pattern of neoplasms in the Sudan [9]. Non-Hodgkin's lymphoma (CD30-ve) is the most common immunophenotype in the Sudan, which represented 79\%, according to the histological evidences. However, up to now there is no detailed study investigated the immunophenotyping of lymphomas in the Sudan. Most available literature from the Sudan dealt with Burkett's lymphoma. During the period 1962-80 thirty-five cases of Burkett's lymphoma were seen and examined histologically in Khartoum, Sudan $[10,11]$.

A retrospective study was performed dealing with clinical and histopathological aspects of Hodgkin's disease in patients presenting to the Radiation and Isotopes Centre of Khartoum (RICK) during the period from January 1984 to January 1989. A total of 105 patients were studied; this number accounted for $30.6 \%$ of all lymphoma patients and $2.0 \%$ of all cancers seen at RICK during the same period [12].

There is paucity of information on childhood cancer from the Sudan. Data was obtained from the hospital registry for the period May 1999 to June 2007 on all paediatric patients presenting to the Institute of Nuclear Medicine and Oncology, University of Gezira, Wad Madani, Sudan. There were 322 children with cancer during this time period with a male: female ratio of 1.6:1. Lymphomas $(111,35 \%)$, leukaemia $(83,26 \%)$ and Wilms' tumor $(43,13 \%)$ were the three most common groups of tumors. Thirty percent of all lymphomas were Burkett's lymphoma; $3.4 \%$ of all childhood cancer cases were nasopharyngeal carcinomas [13].

Phenotyping of lymphomas is considered mandatory for subsequent best patient management. This is now carried out in most cases using a range of antibodies recognizing $\mathrm{T}$ and $\mathrm{B}$ cells in paraffin sections. Although, there are many T-cell-specific markers 
(CD2, CD3, CD7, CD8, and CD45RO) [14] only CD3 was used in this study, and this is one of the limitation of the current study. Antibody to CD3 is currently a key member of such panels, indicating T-cell phenotype [15]. Many antibodies to CD3 are polyclonal with the inherent disadvantages compared to monoclonal antibodies [16]. Monoclonal antibody to human CD3, when used in combination with other antibodies, is regarded as a reliable pan T-cell antibody used in the immunophenotyping of lymphomas in paraffin sections [17]. The diagnostic significance of $\mathrm{CD} 3$, on occasion, it may be possible to diagnose a lymphoma as being of T-cell origin in paraffin sections by demonstrating a minor subpopulation of CD3-positive neoplastic cell [15]. Notable, exceptions include some of the more aggressive, large $\mathrm{T}$ cell lymphomas and anaplastic large cell lymphomas, which may not express detectable antigen [18]. Polyclonal antibody to CD3 immunoreactivity has also been reported in a minority of ReedSternberg cells of Hodgkin's disease and in some B cell $[19,20]$. The identification of such cases indicates that the use of CD3 antibody alone in paraffin sections may lead to an incorrect determination of cell lineage in some B-cell NHL. However, polyclonal CD3 is useful to distinguish between T-cell and B cell lymphomas when used in conjunction with CD20.

Although morphology remains the gold standard in the diagnosis of Hodgkin's disease, immunophenotype is a useful adjunct in differentiating prognostically distinct subtypes. Although, there are many Hodgkin's lymphoma specific markers (CD30, CD 15, CD20, CD45) [21], only CD30 was used in this study, and also this is an other limitation in this study. CD30 is expressed on Hodgkin's ReedSternberg (H-RS) cells, the tumor cells in Hodgkin's disease. Increased levels of serum CD30 are observed in Hodgkin's disease patients and are a good marker for predicting a poor prognosis and a poor response to therapy [22]. CD 30 was expressed in $11(84 \%)$ of cases of Hodgkin's lymphoma in this study. Similar finding was previously reported, when CD30 was expressed in $86 \%$ cases Hodgkin's disease [23]. However, high CD30 expression in classical Hodgkin's lymphoma, as well as, in other lymphomas such as, anaplastic large cell lymphoma $[24,25,26]$, which can be minimized by the use of CD45, which was unaffordable in this study. Furthermore, of the limitation of this work is that this was a retrospective rather than prospective study making it difficult to get good socio-demographic information.

\section{Conclusion}

There is high frequency of T-cell lymphomas among Sudanese lymphoma's patients. Our data suggest that the detection of differentially expressed lymphoma markers, such as CD3 and CD30, may offer a simpler approach to phenotypic classification of T-cell and Hodgkin's lymphoma, respectively. In the future, an approach based on examination of multiple sets of $\mathrm{CD}$ markers may identify additional distinct subtypes of T-cell lymphoma as well as Hodgkin's lymphoma.

\section{Acknowledgements}

We would like to thank the members of the department of histopathology, RICK and The National Laboratory for their cooperation and assistance. We are very grateful to the people at the department of histopathology and Cytology, faculty of medical laboratory sciences, university of Khartoum for their technica help and assistance.

\section{Financial Disclosure}

The authors have no any connection with any company and the work was supported by university of Khartoum.

\section{References}

1. Allison JP, Havran WL (1991) The immunobiology of $T$ cells with invariant gamma delta antigen receptors. Annu Rev Immunol 9: 679-705.

2. Van Dongen JJMKGW, Wolvers-Tettero ILM et al. (1988) Distinct molecular forms of human T cell receptor y/o. Blood 71: 603-612.

3. Anderson C, Rezuke WN, Kosciol CM, Pastuszak WT, Cartun RW (1991) Methods in pathology. Identification of T-cell lymphomas in paraffin-embedded tissues using polyclonal anti-CD3 antibody: comparison with frozen section immunophenotyping and genotypic analysis. Mod Pathol 4: 358-362.

4. Smith CA, Gruss HJ, Davis T, Anderson D, Farrah T, et al. (1993) CD30 antigen a marker for Hodgkin's lymphoma, is a receptor whose ligand defines an emerging family of cytokines with homology to TNF. Cell 73: 1349-1360.

5. Lau SK, Thomas P, Weiss LM (2010) Immunohistochemical Evaluation of CON6D/B5: A New CD30 Monoclonal Antibody. Appl Immunohistochem Mol Morphol 18: 273-277.

6. Geissinger E, Sadler P, Roth S, Grieb T, Puppe B, et al. (2010) Disturbed expression of the T-cell receptor/CD3 complex and associated signaling molecules in CD30+ T-cell lymphoproliferations. Haematologica 95: 16971704.

7. Geissinger E, Sadler P, Roth S, Grieb T, Puppe B, et al. (2010) Disturbed expression of the T-cell receptor/CD3 complex and associated signaling molecules in CD30+ T-cell lymphoproliferations. Haematologica 95: 1697-1704.

8. Ahmed HG, Safi SH, Shumo Al, AbdulRazig M (2007) Expression of Estrogen and Progestrone receptors among Sudanese women with breast cancer Immunohistochemical study. Sudan J Med Sci 2: 5-6.

9. Malik MOA, Sheikh EHEI (1979) Tumors of the eye and adnexa in the Sudan Cancer 44: 293 - 303.

10. Veress B, Malik MO, Satir AA, El Hassan AM (1976) Burkitt's lymphoma in the Sudan. Afr J Med Med Sci 5: 115-119.

11. Yagi KI, Rahman ESA, Abbas KED, Prabhu SR (1984) Burkitt's lymphoma in the Sudan. Int J Oral Surg 13: 517-527.

12. AbuElHassan MS, Ahmed ME, A/Fatah A/Gadir, Hidaytalla A, Ahmed HM (1993) Differences in presentation of Hodgkin's disease in Sudan and Western countries. Trop Geogr Med 45: 28-29.

13. Abuidris DO, Ahmed ME, Elgaili EM, Arora RS (2008) Childhood cancer in Sudan: 1999-2007. Trop Doct 38: 208-210.

14. Jones D, Fletcher CD, Pulford K, Shahsafaei A, Dorfman DM (1999) The T-Cell activation markers CD30 and OX40/CD134 are expressed in nonoverlapping subsets of peripheral T-Cell lymphoma. Blood 93: 3487-3493.

15. Cabecadas JM, Isaacson PG (1991) Phenotyping of T-cell lymphomas in paraffin sections--which antibodies? Histopathology 19: 419-424.

16. Steward M, Bishop R, Piggott NH, Milton ID, Angus B, et al. (1997) Production and characterization of a new monoclonal antibody effective in recognizing the CD3 T-cell associated antigen in formalin-fixed embedded tissue. Histopathology 30: 16-22.

17. Chan JK, Tsang WY, Pau MY (1995) Discordant CD3 expression in lymphomas when studied on frozen and paraffin sections. Hum Pathol 26: 1139-1143.

18. Wood KM, Pallesen G, Ralfkiaer E, Warnke R, Gatter KC, et al. (1993) Heterogeneity of CD3 antigen expression in T-cell lymphoma. Histopathology 22: 311-317.

19. Gómez-Román JJ, Cobo ML, Val-Bernal JF (2008) Anaplastic lymphoma kinase-positive anaplastic large cell lymphoma presenting as a bladde neoplasm. Pathology Int 58: 249-252.

20. Wang J, Chen C, Lau S, Raghavan RI, Rowsell EH, et al. (2009) CD3-positive Large B-cell Lymphoma. Am J Surg Pathol 33: 505-512.

21. Atayar C, van den Berg A, Blokzijl T, Boot M, Gascoyne RD, et al. (2007) Hodgkin's lymphoma associated T-cells exhibit a transcription factor profile consistent with distinct lymphoid compartments. J Clin Pathol 60: 1092-1097.

22. Tumwine LK (2004) Immunohistochemical analysis of Hodgkin's disease in Kampala, Uganda. East Afr Med J 81: 384-387. 
Citation: Ahmed HG, Adam TM, Basama NK, Agabeldor AA (2011) Utility of CD3 and CD30 in Immunophenotyping of Lymphomas Among Sudanese Patients. J Cancer Sci Ther 3: 116-119. doi:10.4172/1948-5956.1000071

23. Su CC, Chiu HH, Chang CC, Chen JC, Hsu SM (2004) CD30 Is Involved in Inhibition of T-Cell Proliferation by Hodgkin's Reed-Sternberg Cells. Cancer Res 64: 2148-2152.

24. Kalyan K, Basu D, Soundararaghavan J (2006) Immunophenotyping of Hodgkin's disease--an aid to its classification. Indian J Pathol Microbiol 49: 173-177.
25. Hirsch B, Hummel M, Bentink S, Fouladi F, Spang R, et al. (2008) CD30induced signaling is absent in Hodgkin's cells but present in anaplastic large cell lymphoma cells. Am J Pathol 172: 510-520.

26. Tumwine LK, Agostinelli C, Campidelli C, Othieno E, Wabinga H, et al. (2009) Immunohistochemical and other prognostic factors in B cell non Hodgkin lymphoma patients, Kampala, Uganda. BMC Clin Pathol 9: 11. 